\title{
Article \\ Evaluating the United Nation's Agenda for Atrocity Prevention: Prospects for the International Regulation of Internal Security
}

\author{
Cecilia Jacob \\ Department of International Relations, Coral Bell School of Asia Pacific Affairs, The Australian National University, \\ 0200 Canberra, Australia; E-Mail: cecilia.jacob@anu.edu.au
}

Submitted: 14 April 2015 | In Revised Form: 2 July 2015 | Accepted: 2 July 2015 |

Published: 27 October 2015

\begin{abstract}
In recent years the UN Secretary-General has promoted mass atrocity prevention as the priority agenda for the Responsibility to Protect (R2P) at the UN, redirecting debates on R2P away from military interventionism towards improved state capacity to prevent atrocity crimes and protect populations. This focus has been illustrated in the UNSG's annual reports on R2P since 2009, and the 2014 "Framework of Analysis for Atrocity Crimes", that emphasise state institutional capacity and the identification of atrocity-risk indicators. Through a case-study of Pakistan, this article problematizes the relationship between internal security and the UN agenda on atrocity prevention to evaluate the viability of promoting atrocity prevention as currently conceived by the Office of the UNSG in high-risk contexts. It argues that an atrocity prevention agenda informed by a responsive regulation framework would be more effective in taking into account the relational dynamics of atrocity crimes. This includes accounting for the interaction between the microdynamics of political violence with macro-dynamics created by lengthy historical conflicts and strategic repertoires.
\end{abstract}

\section{Keywords}

mass atrocity prevention; Pakistan; responsibility to protect; responsive regulation; social contexts of violence

\section{Issue}

This article is part of the special issue "Mass Atrocity Prevention", edited by Professor Karen E. Smith (London School of Economics and Political Science, UK).

(C) 2015 by the author; licensee Cogitatio (Lisbon, Portugal). This article is licensed under a Creative Commons Attribution 4.0 International License (CC BY).

\section{Introduction}

The Offices of the UN Secretary-General (UNSG), and the Special Advisors to the UNSG on the Prevention of Genocide, and the Responsibility to Protect (R2P), have displayed remarkably creative work in recent years in moving forward the international agenda on mass atrocity prevention through the promotion of the R2P principle. Since 2009, UNSG Ban Ki-moon has released annual reports on $\mathrm{R} 2 \mathrm{P}$ and hosted an annual interactive dialogue among member states to foster dialogue and shared understanding of R2P as a norm to respond to mass atrocity crimes both in external states, and internally. This work facilitates, to a large extent, a conceptual reorientation of R2P away from its image as a justification for big powers to intervene in weak states for which it has so long been criticised (Cunliffe, 2010; Hehir, 2013). Rather the UNSG has sought to emphasise the preventative aspects of $\mathrm{R} 2 \mathrm{P}$, and to place particular onus on states to improve their domestic responses to threats of atrocity crimes. ${ }^{1}$ Given the clear efforts within the UN to redirect the language and trajectory of R2P discussions in recent years, this article seeks to do a number of things. In the first section, the article assesses R2P as an atrocity prevention framework to regulate state actors in responding to risk of atrocity crimes within their own sovereign jurisdiction. It is argued that the UNSG's efforts to frame R2P as a "preventive doctrine"

\footnotetext{
${ }^{1}$ The definition of "atrocity crime" in this article are the four crimes addressed by R2P including genocide, ethnic cleansing, war crimes, and crimes against humanity.
} 
(Global Centre for the Responsibility to Protect, 2014) is a significant move given the high level of international support for the preventative pillars. However, the focus of the UNSG's annual reports on R2P remains primarily on macro-structural reform at the state-level, conceptualising prevention as a type of intervention, and overemphasising the causal relation between macrostructural reforms with atrocity prevention.

In the second section, the article illustrates the shortcomings of the current UNSG's approach through a case study of Pakistan. This section examines the dynamics of political violence within Pakistan where atrocities have occurred to reflect on the salience of the UNSG's agenda to prevent atrocity crimes given its specific internal security challenges. This section argues that atrocity crimes inside Pakistan need to be considered in the broader social context of strategic repertoires developed through decades of conflict, both external and internal drivers of violence, and the robustness of civilian protection mechanisms within these states. The article investigates the logic of Pillar One in line with these contextual factors to make a more forceful argument for the reconceptualization of Pillar One that corresponds to the strategic realities of states facing high level risk of atrocity crimes. ${ }^{2}$

In response to this case study, the third section introduces a "social contexts of violence" approach that reconceptualises atrocity crimes through a relational framework (Gerlach, 2006, 2010; Karstedt, 2013). This approach accounts for the historical contextualisation of internal conflicts, and emphasises the interaction between the micro and macro dynamics of political violence that is salient for explaining mass violence in the context of case studies such as Pakistan. Finally, the chapter revisits the question of regulation of internal security, by arguing that a responsive regulation approach (Braithwaite, 2002) is a helpful model for thinking about prevention in a relational context as described by Gerlach and Karstedt. Responsive regulation is both philosophically and practically consistent with $R 2 P$, and serves as a corrective to the externally-driven agenda for atrocity prevention within existing UN frameworks. A responsive regulation approach adds value to the current framework as it places more emphasis on local peacebuilding resources, is attuned to relational contexts of violence, and promotes a philosophy of restorative justice that is found to be much more culturally salient and preferable to coercive external intervention in societies facing violent conflict and the risk of atrocity crimes.

\section{Conceptual Constraints on Pillar One}

Prevention has always been an integral aspect of the

\footnotetext{
${ }^{2}$ For an analysis of Pillar One in relation to states facing a lower level of risk of atrocity crimes, see Jacob (2015)
}

R2P doctrine since its inception in the 2001 International Commission on Intervention and State Sovereignty (ICISS) report on R2P. Paragraph 138 of the 2005 UN World Summit Outcome Document, unanimously endorsed by over 150 heads of state at the Summit, affirms the state's responsibility to prevent and protect its population from the four atrocity crimes of genocide, war crimes, ethnic cleansing and crimes against humanity, now referred to as "Pillar One" responsibilities of the state (UN, 2009). Moving forward from principle to practice however has been a concern of R2P advocates (Bellamy, 2011; Evans, 2008; Thakur, 2011; UNGA, 2009). Whereas states unanimously endorsed the principle of state's primary responsibility for atrocity prevention at the World Summit in 2005, efforts by the UN to put flesh on the bones of this commitment only started four years later, and has gained its most significant traction through the UNSG's annual reports on R2P in 2013 and 2014 on Pillars One (state sovereign responsibility) and Two (international assistance) respectively.

The decision by the UNSG to provide deeper clarification of R2P in operational terms for prevention is an indication that R2P is increasingly being accepted at the international level to serve a regulatory function in global governance, even though its legal status remains imprecise (Rosenberg, 2009; Stahn, 2007; Strauss, 2009; Welsh \& Banda, 2010). The most sophisticated policy and operational guidelines for atrocity prevention still focus on defining multilateral and national toolkits and responses to external crises in other parts of the world however (Albright \& Williamson, 2013; Giffen, 2010; Meyer et al., 2013; Sharma \& Welsh, 2012; UN, 2014; Waxman, 2009), with the specification of Pillar One duties for states own domestic institutional, legal and political reforms still largely indicative.

The UNSG's 2013 Report Responsibility to protect: State responsibility and prevention does emphasise a wide range of domestic sites for intervention and reform to build state resilience to atrocity crimes. Specifically the report points to risk factors such as underlying patterns of discrimination and lack of accountability for past atrocity crimes as crucial areas for domestic prevention interventions. Sources of state resilience to atrocity crimes are cited in the UNSG's 2013 Annual Report on R2P, namely constitutional protections (paragraph 35), democratic electoral process (paragraph $37)$, the criminalisation of genocide, war crimes and crimes against humanity (paragraph 40), national accountability mechanisms (paragraph 41), transitional justice processes for past atrocity crimes (paragraph 42 ), security sector reform (paragraph 43), poverty reduction and economic equality (paragraph 45). Further the report identifies a national infrastructure for the promotion and protection of human rights, the rule of law and strong governance, and the mainstreaming of atrocity prevention within national administrations as 
crucial institutional sites for atrocity prevention that build on the need for structural resilience.

The reorientation of the R2P discourse away from external interventionism is clearly a significant achievement. The 2014 UNSG report on R2P "Fulfilling our collective responsibility: international assistance and the responsibility to protect" builds on this reorientation by calling on states to reinforce the Pillar One capacity of states. However, the expectations on states for nation-wide capacity building, structural reform and institutional change are resource intensive, and geared heavily towards a governance, rule of law, and capacity building agenda at the macro-level that to a large extent sidelines a state's own experiences and internal dynamics of political violence. This focus is clearly articulated in the 2014 UNSG report on R2P:

Preventive action at this stage (of general risk) requires more structurally focused strategies designed to help to build national resilience. The principle objective is the creation of State structures and institutions that are functioning and legitimate, respect human rights, and the rule of law, deliver services equitably, and can address or defuse sources of tension before they escalate. (A/68/947S/2014/449, p. 4, paragraph 8)

The 2014 Atrocity Prevention Framework released by the Office of the Special Representative to the UNSG on the Prevention of Genocide argues that atrocities are "processes", yet makes a similar case that investing in the rule of law, legitimate and accountable national institutions, corruption, management of diversity and support for civil society and an open media have a direct causal relationship with the prevention of atrocity crimes, arguing: "[f]ailure by the State to provide such protection and guarantees to its population can create an environment conducive to atrocity crimes." (UN, 2014 , p. 3). Accordingly it sets out a series of 14 risk factors that analysts can use to identify potential atrocity crimes.

While each of these areas of reform are crucial, and by no means contested in this article, the purpose of this assessment is to unpack some of the assumptions underlying the atrocity prevention framework that is used to define the contents and responsibilities of Pillar One for states. This agenda, I argue, is too narrow a vision for defining Pillar One per se, and pre-empts the potential significance of Pillar One as a much more ubiquitous and significant reorientation in thinking about states sovereign responsibility. States and key civil society actors should pay heed to the specific policy and legal recommendations embodied in existing atrocity prevention frameworks, however more work is still required in the R2P literature to conceptualise Pillar One responsibilities in the context of states' complex internal security settings .
The following section turns to the case of Pakistan, a state that experiences periodic attacks on civilians, to consider an example of the type of context in which atrocity prevention efforts need to be conceptualised. State security practices in this state are historically contingent, and not just symptoms of poor governance or the need for security sector reform in terms of capacity and organisation. The next section argues that for Pillar One prevention duties to be fully realised, there needs to be a much broader project of historical reinterpretation of internal conflicts and significant long-term reform in security practices that have developed over decades of militarisation. Pillar One duties of states are further complicated by international dynamics - such as the US presence in Afghanistan and air-strikes on the Taliban in Pakistan. Acknowledging social, political and historical contingency surrounding recent atrocity crimes in this state challenges the dominant conception of the range of responsibilities and contexts in which Pillar One duties of states correspond to. It provides the basis for an argument that is geared towards responsive regulation based on principles of restorative justice. This approach, it will be argued, is preferable to linear models of prevention that are conducive to ratcheting up punitive responses and violent escalation than seeking to find alternative, non-escalatory pathways when violence is imminent.

\section{Pakistan: Conflict Trajectories and State Interpretation Pillar One Duties}

On 16 December 2014, 141 people-including 134 children-were killed in an attack by the Pakistani Taliban on a military school in Peshawar. The attack was retribution for the government's anti-insurgency campaign in North Waziristan and the Khyber area. This is just one of the many atrocities committed by the Taliban against civilians and government targets in just over a decade, and takes place in the context of a broader national upsurge in multiple insurgent fronts, and antisectarian violence targeting Shi'a, Christian, Ahmadi and Hindu minorities (USCRIF, 2013, pp. 177-183).

Tracing these events back slightly further, we note that Western airstrikes in the early years of the 2001 war in Afghanistan exacerbated the divide been the Uzbek and Tajik populations of the north and the aggrieved Pashtun's in the South that caused many Pashtun Taliban fighters across the border into Pakistan's North West Frontier Province. The entrenchment of the Taliban movement in Pakistan has been effective in gradually galvanising a number of Sunni insurgents already operating in Pakistan (Kanwal, 2013), particularly a younger generation drawn more to an internationalised brand of Islamic militancy over fragmented tribal separatist ideologies. Indeed the Taliban tends to draw the sympathy of junior ranks of the army and the InterServices Intelligence (ISI) (Johnson, 2011, pp. 167-168), 
and many Pashtun soldiers have deserted the army, not wanting to fight fellow Muslims (Kanwal, 2013, p. 2 ). These trends have significantly affected the morale of the Pakistani security forces in conducting their counter-insurgency operations.

In Afghanistan, the Taliban has grown from an estimated 2,000 fighters in 2002 to over 60,000 today (Council on Foreign Relations, 2015), with thousands of Taliban fighters spilling over the borders into Pakistan. Pakistan's decades-long military strategy of fostering insurgency in Afghanistan to buffer its own national security by achieving "strategic depth" has caused a severe blow-back with the creation of the Pakistani Taliban since the U.S.-led invasion in Afghanistan. The Pakistani Taliban movement is seeking a revolution against the "apostate" Pakistani government due to its support for the Western-led invasion into Afghanistan. Following decades of fostering insurgency in Afghanistan, the Pakistani military has in recent years turned its focus towards countering insurgency on its own territory (Mullick, 2009).

As the 2014 school attack illustrates vividly, the interventionist pathways taken both by Western powers and Pakistan in Afghanistan since 2001, and the counter-insurgency strategies taken by the Pakistani security forces have to date lead to the escalation of violence in which thousands of Pakistani civilians have become direct targets, including bombings on civilians sites such as places of worship by militant groups, and widespread fatalities and displacement caused by the military's counter-insurgency operations. Between 2003 and March 2015, an estimated 20,228 civilians and 6,111 security personnel have been killed through terrorist violence alone in Pakistan. Some 30,695 terrorists and insurgents have been killed during this same period (SATP, 2015). The Pakistani government and military, divided as they are, view the Pakistani Taliban through the lens of internal security and state cohesion. Many of these internal security issues are the result of a long trajectory of policy choices favouring military escalation to deal with Pakistan's internal divisions along tribal, ethnic and religious lines since the early 1970s (Gazdar, 2006; Khan, 2012), particularly after the loss of East Pakistan in 1971.

Given this brief historical context in which to understand the killings of 141 civilians in 2014 and similar attacks (e.g. Craig, 2014) where do R2P responsibilities of the state to prevent and protect populations fit into the picture? In historical perspective, Pakistan's R2P obligations are very recent and are unenforced. The choices made in pursuing military options to internal crises are the consequence of a number of overarching factors including decades of strategic repertoires that resort to militarised repression of internal dissent, the internationalised conflict against the Taliban including U.S. air-strikes on Pakistan's soil that have exacerbated internal divisions, and significant U.S. funding to Paki- stan's military that disproportionately privileges this sector. Furthermore, the current threat to civilian lives in Pakistan is periodic rather than sustained, low enough in numeric terms and shielded by geopolitical sensitivities of powerful states not to be considered a Pillar Three external intervention. In terms of R2P thinking, the expectations are that the state can and should be able to manage the atrocities such as the school bombing through their own domestic capacity. While this is a reasonable expectation, further thinking on what kind of actions constitute Pillar One responsibilities need to be clarified in this context.

The state of Pakistan has openly endorsed R2P, including Pillar One on the prevention and protection of civilians from atrocity crimes. At the UN General Assembly informal interactive dialogue on the Responsibility to Protect in 2014, the representative of Pakistan Ambassador Masood Khan stated:

The basic thrust of the first two pillars is to prevent atrocity crimes by building societies on the basis of reconciliation, justice and security. R2P response should not be activated only after eruption of or a full- blown armed conflict.

The Pakistan Ambassador qualified his support more explicitly by stating: "There should be no exceptionalism in pursuit of the goal of protection of civilians. Palestine is a case in point."

The Ambassador summed up the Pillar One principle with powerful acknowledgement of reconciliation, justice and security within societies as core responsibilities of states towards their own population. Indeed Pakistan's experience with Muslahathi Committee's to bridge traditional and state law and order systems evidences their recognition of the need for restorative justice approaches in a number rural spaces where the Taliban have gained popular support (Braithwaite \& Gohar, 2014). However, the reference to Palestine shifts the focus away from the internal situation in Pakistan to which such statements are highly relevant. It also engenders a UN culture in which states are apt at identifying appropriate cases where R2P is relevant rather than embracing a more reflective stance on the internal security situation being faced in the home state.

Pillar One clearly has significant implications for regulating the counter-insurgency and civilian protection efforts within states, but I argue here that the scope of Pillar One as articulated in UN and related documentation separates the international prevention agenda from these contextual settings of political violence, including historical military trajectories and regional and international drivers, in which atrocities occur. This separation is consequently replicated and entrenched in state conceptualisations of Pillar One that fail to see their international obligations on R2P associated with their internal security objectives. 
Therefore, in the case of Pakistan, the assumption underlying the principle UN documentation - that addressing a number of macro indicators related to governance and rule of law, security sector reform and human rights constitutes the Pillar One responsibilities of states-is misplaced for two reasons. First, it is not founded on an empirical basis for identifying the contexts in which atrocities occur but rather responds to a generic framework of structural factors supposed to have a causal relation with atrocity crimes. Second, it assumes that the actions and responsibilities of the state in relation to atrocities within its domestic jurisdiction are independent and prior to international assistance. It does not allow for historical and political complexity in which a range of domestic and international factors are at play in setting the trajectory of political violence and atrocity crimes at the domestic level. As such it places heavy onus on the state for reversing lengthy historical trajectories, and vilifies the state when it is deemed unable or unwilling to protect its own populations from atrocity crimes that are manifestations of broader intractable internal security quagmires. The "failure" of states on Pillar One duties therefore is deemed to warrant international condemnation and assistance and curtails the consideration of alternatives prior to external intervention (military or non-military) in which R2P may be considered a useful framework for preventing atrocity crimes.

Pakistan's experience brings into question the salience of equating Pillar One duties with a predetermined atrocity prevention policy framework in states facing protracted insurgency, secessionism or terrorism that have not been considered as R2P cases for Pillar Three external intervention yet face a high level of risk of atrocity crimes being committed against domestic populations. It also indicates that there are more specific considerations that need to be foregrounded in this agenda that include military repertoires, both external and internal drivers of violence, and the robustness of civilian protection mechanisms within these states. The next section considers the conventional logic surrounding Pillar One to explain why it has been so narrowly conceptualised to date in the R2P literature, before moving to consider alternative and more productive ways to conceptualise this aspect of R2P.

\section{Reconceptualising Pillar One in Strategic Context}

In 2012, Williams, Ulbrick and Worboys argued that there is a step missing in Pillar Three of R2P, namely the lack of a capacity for international coercive intervention when the UNSC fails to mandate action in the face of mass atrocities such as those in Syria. They outline criteria through which the limited use of force by the international community could be imagined without UNSC authorisation to ensure that R2P operates as intended. They argue that "[a]lthough the use of force without Security Council authorization is a complicated and delicate question' their criteria for permitting nonUNSC authorized international military intervention is 'the most appropriate way to develop R2P moving forward." (Williams, Ulbrick, \& Worboys, 2012, p. 476).

If it is the case that R2P is "missing a step" in terms of its most punitive and coercive capacity, it is also the case that there is a need to unpack the assumptions surrounding prevention embedded in the logic of the R2P doctrine to create more space at the less coercive end of the R2P spectrum to successfully protect populations from atrocity crimes. The conventional story told about the prevention element of R2P in the literature is as follows:

First, individual states [are] primarily responsible for protecting their populations. ICISS categorized this aspect of the R2P as a state's "responsibility to prevent," outlining a state's obligation to eliminate the root causes of mass atrocities. (Williams et al., 2012, p. 482)

There are several assumptions embedded in this account that elucidates the reasons why these authors feel that Pillar One options are all too readily exhausted in the context of conflict scenarios, and that more rigorous capacity to resort to interventional military interventions is necessary. The first assumption is that prevention can be dealt with in isolation by states as a first step in a three tiered process. This assumes an inward-focussed state that has the capacity and will to counter domestic instability or conflict that is on an upward trajectory towards mass atrocity before it reaches an imminent stage. The situation in Pakistan requires us to take a step back to think about the multiple trajectories, and complicating factors related to geostrategic interest, national security calculations and military repertoires that unsettle this standard definition of what Pillar One means in the context of states. This also helps us to understand how states could conceivably endorse Pillar One in international forums without interpreting it as relevant to these proximate factors.

Pakistan's foreign policy goal of creating strategic depth in Afghanistan is a significant factor in its national security calculations, previously to serve as a buffer from the Soviet Union and to prevent Indian encirclement of its territory. This strategy has driven Pakistan's involvement in fostering insurgency in Afghanistan since the CIA created and supported the Afghani mujahedeen in the 1980s. Pakistan became the state most affected by terrorism following the U.S.-led invasion into Afghanistan and faces an intractable insurgency and radicalisation. Its internal security situation is therefore not an isolated case for which the Pakistan state is solely responsible-external factors such as dispropor- 
tionate U.S. funding of the Pakistani military over other forms of assistance has facilitated its propensity towards militarised responses to domestic problems.

Many of these problems are of course not just the fault of external actors such as the U.S., and the Pakistani military is reaping much of the destruction that it has sown in Afghanistan, but the point here is that these broader geostrategic dynamics are part of the Pillar One spectrum in which prevention and protection efforts at the state level need to be conceptualised. I would like to bracket here that international responsibility in the context of prevention is just as much about not creating the conditions for quagmires in states as it is about external response in perceived failed statesthis is an element that is absent in discussions on Pillar One but one that can be seen at the heart of many of today's protracted conflicts in which atrocity crimes are persistent features. The international community is not just the post-hoc solution to state failure on atrocity crimes, but is constitutive of the Pillar One context in which states are expected to act.

The second assumption embedded in the conventional account of Pillar One is that prevention corresponds to an "obligation to eliminate the root causes of mass atrocities", thereby assuming an anachronistic perspective of the trajectory of violence and internal conflicts in which atrocity crimes take place. Again here it is assumed that the so-called "root causes" are independent variables that can be isolated and eliminated through targeted state reforms. Yet this conceptualisation does not permit us to consider atrocities in terms of the lengthy historical trajectories through which they have emerged, or the relational context in which they are manifested. In the case of Pakistan, how might we "eliminate" root causes such as the process of nation-building, the geographic concentration of political power and resourcing in the province of Punjab, the perpetual anxiety over national cohesion that has guided its counter-insurgency campaigns since the 1970s, and its geo-strategic concern with achieving strategic depth in Afghanistan to mitigate India's strategy of encirclement. Without these contextual factors, it is impossible to explain the rise of Sunni-insurgency and the related surge in sectarian violence in Pakistan to which recent atrocities are attributed.

Here then, what we need to be concerned about is not just eliminating root causes per se, but rather changing trajectories that have been set in motion by responding to strategic repertoires. In this regard, the Pakistani military has been effective in gradually reducing collateral damage and improving the protection of displaced populations through its counter-insurgency strategy since 2009 when collateral damage became an important political factor at the national level (Mullick, 2009). Conceived this way, Pillar One should align much more closely with the strategic realities on the ground, given the rather utopian prospect of eliminat- ing root causes before they lead to mass atrocity in contexts where political violence is already well entrenched. It also means however that Pillar One reconceptualised is a much broader project, and much more ubiquitous than the limited and rare occasions in which coercive international interventions under a R2P pretext could be warranted.

The next section introduces the literature on the social contexts of violence to challenge the empirical basis on which core Pillar One assumptions are founded. It argues that a relational approach to understanding the interaction between macro and micro-dynamics of violence provides a stronger basis on which to build a conceptualisation of Pillar One in the R2P literature that to date is not yet developed.

\section{Rethinking Prevention through a Social Contexts of Violence Approach}

In recent years there has been a growing interest in international relations and political science that is concerned with the micro-dynamics of violence at the local level (Auteserre, 2010; Kalyvas, 2006; Lemarchand, 2009) for explaining the large-scale armed conflicts and genocides that shape regional and international security. Simplified explanations or macro-narratives of conflicts such as those centred on ethnic rivalry in Rwanda and the Democratic Republic of Congo circumvent international understandings of the complex microsociological causes and dynamics of mass violence (Straus, 2008) that are often counter-intuitive to the macro-narrative, and cause expansive international peacekeeping efforts to repeatedly fail (Auteserre, 2010; Kemp et al., 2013).

The development of this important body of literature has significant implications for thinking about atrocity prevention. Scholars such as Susanne Karstedt (2013) argue that while genocides are rare, atrocities are much more common, and today tend to feature as events that "are of a smaller scale and reiterated" as opposed to mass genocides. Mass atrocities are conceptualised as part of broader trajectories of violence, embedded within historical contexts of social conflict, and therefore highly responsive to dynamic deterrence during the path of escalation to alter these trajectories (Braithwaite, 2014; Karstedt, 2013, p. 385; Klusemann, 2012, pp. 473-475).

Christian Gerlach, in developing a relational approach to the study of "extremely violence societies", $(2006,2010)$ argues that conventional studies of significant twentieth-century genocides have presented a narrow account of the dynamics of mass atrocities that have confined our understanding of such events. Firstly, conventional assumptions contained within studies of genocide focus on ethnicity/race or other singular elements of intent as a cause for systematic, one-sided violence. Where they do acknowledge multi-causality, 
they still seek to single out a dominant explanatory factor. Secondly, conventional studies seek to explain genocide in terms of a neat categorical distinction that is separate from other forms of social violence, rather than seeking to identify the linkages between them. And finally, such studies emphasise the role of the state (genocide as a state crime) rather than on broad and multiple levels of social interactions where widespread mobilisation of populations is vital for explaining how violence can take place on a mass scale.

One of Gerlach's critiques of contemporary genocide studies is that it is heavily biased towards the state and structural mechanisms to prevent such violence that "work towards simplification and against contextualisation." (2006, p. 465). This assumption has to a large extent carried through to most atrocity prevention frameworks that place primary emphasis on governance, rule of law, and security sector reforms at the macro-level. While the UN's current approach to atrocity prevention has been broadly influenced by the fields of criminology, peace and conflict studies and public health (Sharma \& Welsh, 2012), a sociological perspective contributes a complex picture of atrocity crimes (eg. Bakonyi \& De Guevara, 2009; Kalyvas, 2006) that point towards the need for a dynamic and contextualised model of atrocity prevention for violence at the sub-national level.

Following on from these conclusions, Karstedt (2013) has argued that there is a move within genocide studies towards conceptualisations of atrocity crimes that have more legal and analytical relevance to the nature of contemporary political violence. The UN approach to atrocity prevention not only tends to focus on the macro level of state institutions and structures, but the prevention models that inform its approach assume a linear path of crisis escalation from risk through to imminence (Evans, 2008, p. 87; Sharma \& Welsh, 2012). History shows however that micro-level violence below the state and systemic/regional violence peak and decline in non-linear trajectories, and conflict trajectories are shaped by the interaction between these micro-social processes with the macro-structures. (Berenschot, 2011; Braithwaite \& D'Costa, 2012; Kalyvas, 2003, 2006; Karstedt, 2013, p. 386; Sanín \& Wood, 2014; Tilly, 2003; Weinstein, 2007). A relational approach to the study of mass atrocity crimes therefore does not assume a Galtung-model of structural and cultural violence that makes societies prone to atrocities, but rather traces the events and trajectories that led to a specific event of genocide.

Another key limitation of models of structural preventions is that they assume a direct causal relationship between "root causes" and violence without contextualising the dynamics through which these root causes will develop into various forms of violence. It relies on "external diagnosis and prognosis" of risk that bypasses sources of domestic and local resilience
(McLoughlin, 2014, p. 410). In doing so, such models also de-emphasise the benefits of alternative approaches to prevention through empowering local agency and resilience of populations where history has proven that local strategies of escape and survival have prevented the greatest numbers of deaths from mass atrocity crimes (Mayerson, 2014). Indeed a number of scholars have begun to focus on agency where selfprotection strategies are demonstrated to be crucial for survival well before international assistance is forthcoming (Baines \& Paddon, 2012; Kaplan, 2013; Mégret, 2009)

The implications of a relational approach to mass atrocities for assessing the current UN atrocity prevention strategy is to question the general "nature" of a state as prone to such crimes based on an assumed causal relationship between given state structures with the likelihood of atrocity crimes. A relational understanding of mass-atrocity crimes is to some extent counter-intuitive to the central thrust of the UN's current approach to mass-atrocity prevention, as it argues for the need to recognise that both resistors and participants of violence are found in the same society, that violence ebbs and flows with peaks, and that broad social participation (alliances/coalitions) are needed for such extensive violence to take place. It is not questioned here that core governance and rule of law institutions such as the judiciary and security sector are crucial for successful prevention of atrocity crimes. What is argued here is that this emphasis on structural reform at the state level alone is inadequate without taking into account the micro-sociological dimensions of atrocity crimes at the sub-national level, and how those dynamics then interact with the macro and systemic levels. As the case-study on Pakistan illustrates, each of these levels are interconnected and shape the unique trajectories of conflict and mass violence in different ways. There is a need for a responsive approach to these social contexts of violence than is envisaged in multilateral atrocity prevention toolkits, as these place a heavy emphasis on escalation towards more coercive interventions.

\section{Responsive Regulation: An Alternative Framework for Considering the Regulation of Atrocity Prevention}

The purpose of this article has been to assess the UN's agenda on mass atrocity prevention, noting in the introduction that UN efforts to clarify R2P implementation frameworks point to an increasing regulatory role that R2P is occupying at the international level. In particular, recent reports published by the UNSG provide the basis for a legal and policy framework to guide state responses to atrocity crimes. These reports include recommendations for enhanced accountability of states on R2P duties to the international community through processes such as the Universal Periodic Re- 
view in the UN Human Rights Council (UN, 2014). In this concluding section of the article, I briefly consider responsive regulation as an alternative regulatory model for R2P that complements these existing recommendations, yet accounts for a more dynamic and contextualised understanding that responds to both the micro and macro processes of atrocity crimes.

Responsive regulation is a dynamic framework in criminology that is based on the belief that because social conflict is relational, regulation will be more effective if it is responsive to the social contexts it seeks to regulate (Braithwaite, 2014). It promotes a philosophy that restorative justice is preferable to retributive justice, arguing that restorative models of justice are culturally salient for the prevention of crime in most parts of the world; and that the resort to coercive escalations is mitigated by inclusive dialogue that draws on local conflict resolution resources (Braithwaite, 2002). Responsive regulation seeks to avoid orthodoxy and rigidity in regulatory frameworks which to date has been a stumbling block for atrocity prevention efforts by external actors such as the European Union (Meyer et al., 2013) in responding to unique and contingent internal security environments.

A responsive regulation pyramid has at its widest base options for dialogue and reconciliation to build peace within communities and deter criminal acts. The pyramid allows for the capacity to resort to more coercive forms of enforcement as one moves up the pyramid, where punitive action would be warranted in the most extreme cases of criminal violation. What differentiates a responsive regulatory approach to criminal deterrence from traditional approaches is that it is concerned with pushing prevention strategies "down" the pyramid towards dialogic and restorative methods. Rather than moving up the pyramid to more coercive options when a restorative approach fails, responsive regulation seeks to widen the base by exploring alternative options that draw on local peacebuilding resources.

$\mathrm{R} 2 \mathrm{P}$ reflects the pyramid to a large degree in that prevention at the base of the pyramid (Pillar One) is considered the preferred option, before escalating up towards coercive intervention at the peak of the pyramid (Pillar Three). ${ }^{3}$ Yet current conceptualisations of R2P look rather like an upside-down pyramid whereby the broadest focus in the scholarly literature has tended to emphasise the most punitive and coercive end of the spectrum for assessing its conceptual validity and success. For this reason, I am arguing that R2P could be a much more effective regulatory framework in relation to the internal security concerns of states if states had much more accountability and incentive to push down the pyramid towards responsive, restorative ap-

${ }^{3}$ For a model of R2P crisis escalation and response see Sharma and Welsh (2012) proaches towards atrocity prevention. This includes expanding the creative options available in the articulation of Pillar One than currently exists in international atrocity prevention frameworks.

One clear example of the saliency of this approach to dealing with the prevention of atrocity crimes is found in the work by John Braithwaite and Ali Wardak on the rule of law in rural Afghanistan (2013a, b). These authors argue that the rise of the Taliban, and the ensuing atrocities that occur under their authority, was enabled by a lack of order and legitimate authority in rural Afghanistan. The fragmentation of the Afghan state following the Soviet invasion, and the subsequent rise of externally-backed armed Mujahedeen groups created competition for authority in rural areas where a power vacuum exists. US-led intervention into Afghanistan in 2001 pursued a "Hobbesian" solution by backing a leviathan government under Hamid Karzai, and supporting a strong, centralised state that failed to bring order or a legitimate rule of law in these rural spaces (Braithwaite \& Wardak, 2013a). These conditions have enabled the Taliban to flourish, and so Braithwaite and Wardak offer a "Jeffersonian alternative" (Braithwaite \& Wardak, 2013b) to state-building, arguing that macro-level state building efforts need to work in support of local justice systems, such as the jirga/shura courts to offer a legitimate alternative to rule of law provision in rural spaces that could draw away popular support from the Taliban.

Pakistan's limited experience of creating hybrid formal and traditional justice mechanisms through Muslahathi Committees (Braithwaite \& Gohar, 2014) likewise demonstrate that employing restorative justice approaches within a rule of law framework limit local violence, increase the accountability of police to civil society, and play a role in preventing armed conflict. These context-specific responses support the rule of law and transitional justice as promoted in the UNSG's 2013 and 2014 reports, yet they conceptualise regulation in more dynamic, contextualised and locallysalient framework.

A recent survey conducted among the local population in Syria found that despite overwhelming decline in a desire for an internationally brokered peace settlement to end the conflict, there was widespread support for locally brokered ceasefires between warring communities - a strategy that some consider to be the most feasible option to scaling down the violence, the director of the study notes:

[T]here was also a surprising degree of interest in traditional ceremonies of reconciliation at the local level, sulha and musalaha, ceremonies which involve apology, compensation, and the reestablishment of relations among neighbours. If the national conflict can be worked out there may be ways for people to use these kinds of local and tra- 
ditional ceremonies to coexists, if not live in harmony. (Hoge, 2015)

These local traditional justice mechanisms discussed in these examples illustrate ways that responsive regulation can be conceptualised to promote justice and prevent atrocity crimes in societies facing high levels of risk of atrocity crimes. By emphasising social, political and historical contingency, this approach is well aligned with research on the micro-dynamics of political violence that is linked to mass atrocity crimes discussed previously in this article, and therefore offers an important resource for considering how international regulation of internal security to prevent atrocities may be conceivable.

This article concludes therefore by suggesting that a constructive research agenda should be built on a fuller consideration of the restorative elements for national peacebuilding and atrocity prevention that gives greater attention to the Pillar One duties of states. Pillar One, it has been argued here, is much more ubiquitous than is currently recognised given the narrow conceptualisation of Pillar One as synonymous with prevention frameworks. A broader conceptualisation of Pillar One should consider these prevention frameworks as useful tools among other options in the larger effort to locate and redirect the historical trajectories of conflict and deeply entrenched repertoires of state security actors to promote sovereign responsibility towards domestic populations.

\section{Acknowledgments}

The author would like to thank John Braithwaite, Susanne Karstedt and Stephen McLoughlin for helpful discussions, as well as well as three anonymous reviewers for their comments, that greatly improved this article. All shortcomings are the author's own.

\section{Conflict of Interests}

The author declares no conflict of interests.

\section{References}

Albright, M. K., \& Williamson, R. S. (2013). The United States and R2P: From words to action. Washington: Brookings, United States Holocaust Memorial Museum and United States Institute of Peace.

Auteserre, S. (2010). The trouble with the Congo: Local violence and the failure of international peacebuilding. New York: Cambridge University Press.

Baines, E., \& Paddon, E. (2012). "This is how we survived": Civilian agency and humanitarian protection. Security Dialogue, 43(3), 231-247. doi:10.1177/0967010612444150

Bakonyi, J., \& De Guevara, B. B. (2009). The mosaic of
violence-An introduction. Civil Wars, 11(4), 397413. doi: 10.1080/13698240903411298

Bellamy, A. J. (2011). Global politics and the responsibility to protect: From words to deeds. London and New York: Routledge.

Berenschot, W. (2011). Riot politics: Hindu-Muslim violence and the Indian state. New York: Columbia University Press.

Braithwaite, J. (2002). Restorative justice and responsive regulation. New York: Oxford University Press.

Braithwaite, J. (2014). Limits on violence; limits on responsive regulatory theory. Law \& Policy, 36(4), 432-456.

Braithwaite, J., \& D'Costa, B. (2012). Cascades of violence in Bangladesh, peacebuilding compared working paper. Canberra: RegNet, The Australian National University.

Braithwaite, J., \& Gohar, A. (2014). Restorative justice, policing and insurgency: Learning from Pakistan. Law and Society Review, 48(3), 531-561. doi: 10.1111/lasr.12091

Braithwaite, J., \& Wardak, A. (2013a). Crime and war in Afghanistan: Part I: The Hobbesian solution. British Journal of Criminology, 53, 179-196.

Braithwaite, J. \& Wardak, A. (2013b). Crime and war in Afghanistan: Part II: A Jeffersonian alternative? British Journal of Criminology, 53, 197-214.

Council on Foreign Relations. (2015). The Taliban. Retrieved from http://www.cfr.org/terroristorganizations-and- networks/taliban/p35985?cid= marketing_use-taliban_infoguide-012115\#!/

Craig, T. (2014, January 15). Sectarian killings soar in Pakistan, raising fears of regional spillover. Washington Post.

Cunliffe, P. (2010). Dangerous duties: Power, paternalism and the "responsibility to protect".

Review of International Studies, 36, 79-96. doi: $10.1017 / \mathrm{S} 0260210511000076$

Evans, G. (2008). The responsibility to protect: Ending mass atrocities once and for all. Washington: The Brookings Institute.

Gazdar, H. (2006). Counter-insurgencies in Pakistan. Economic and Political Weekly, 41(20), 1952-1953. doi:150.203.230.231

Gerlach, C. (2006). Extremely violent societies: An alternative to the concept of genocide. Journal of Genocide Research, 8(4), 455-471. doi:10.1080/ 14623520601056299

Gerlach, C. (2010). Extremely violence societies: Mass violence in the twentieth-century world. Cambridge: Cambridge University Press.

Giffen, A. (2010). Addressing the doctrinal deficit developing guidance to prevent and respond to widespread or systematic attacks against civilians. Washington: Stimson Center.

Global Centre for the Responsibility to Protect. (2014). Summary of the sixth informal interactive dialogue 
of the UN General Assembly on the responsibility to protect. New York: Ralph Bunche Institute for International Studies.

Hehir, A. (2013). The permanence of inconsistency: Libya, the Security Council, and the responsibility to protect. International Security, 38(1), 137-159. doi:10.1162/ISEC_a_00125

Hoge, W. (2015, April 3). Hearts have hardened, but Syrians still believe in reconciliation: Q\&A with Craig Charney. IPI Global Observatory. Retrieved from http://theglobalobservatory.org/2015/04/syria-isisassad-united-nations/

International Commission on Intervention and State Sovereignty. (2001). The responsibility to protect. Ottawa: International Development Research Centre.

Jacob, C. (2015). State responsibility and prevention in the responsibility to protect: Communal violence in India. Global Responsibility to Protect, 7(1), 56-80.

Johnson, R. (2011). Jihad and the "war on terror": Intelligence, ethics, and justice in Pakistan and Afghanistan. In M. Phythian \& A. Bergman (Eds.), Intelligence ethics and the war on terror (pp. 166186). Oxon: Routledge.

Kalyvas, S. N. (2003). The ontology of "political violence": Action and identity in civil wars. Perspectives on Politics, 1(3), 475-494.

Kalyvas, S. N. (2006). The logic of violence in civil war. New York: Cambridge University Press.

Kanwal, G. (2013). Pakistan's internal security challenges: Will the military cope? (Issue Brief No. 230). New Delhi: Institute of Peace and Conflict Studies.

Kaplan, O. (2013). Protecting civilians in civil war: The institution of the ATCC in Colombia. Journal of Peace Research, 50(3), 351-367. doi:10.1177/ 0022343313477884

Karstedt, S. (2013). Contextualizing mass atrocity crimes: Moving toward a relational approach. Annual Review of Law and Social Science, 9, 383-404. doi:10.1146/annurev-lawsocsci-102612-134016

Kemp, W., Shaw, M., \& Boutellis, A. (2013). The elephant in the room: How can peace operations deal with organized crime? New York: International Peace Institute.

Khan, H. (2012). Counterinsurgency (COIN) strategy and protracted insurgency in Pakistan's Federally Administered Tribal Areas (FATA). Tigah: A Journal of Peace and Development, 2, 102-103. FATA Research Centre, Islamabad.

Klusemann, S. (2012). Massacres as process: A microsociological theory of internal patterns of mass atrocities. European Journal of Criminology, 9(5), 468-480.

Lemarchand, R. (2009). The dynamics of violence in central Africa. Philadelphia: Pennsylvania University Press.

Mayersen, D. (2014). Rethinking approaches to preven- tion under the responsibility to protect. Global Responsibility to Protect, 6(4), 483-507. doi:10.1163/ 1875984X-00604007

McLoughlin, S. (2014). Rethinking the structural prevention of mass atrocities. Global Responsibility to Protect, 6(4), 407-429. doi:10.1163/1875984X00604004

Mégret, F. (2009). Beyond the "salvation" paradigm: Responsibility to protect (others) vs the power of protecting oneself. Security Dialogue, 40(6), 575-95. doi:10.1177/0967010609350632

Meyer, C., Smith, K. E., De Franco, C., Peral, L., \& Strauss, E. (2013). The EU and the prevention of mass atrocities: An assessment of strengths and weaknesses. Budapest: Budapest Centre for the International Prevention of Genocide and Mass Atrocities.

Mullick, H. A. (2009). Pakistan's security paradox: Countering and fomenting insurgencies. Hurlburt Field: Joint Special Operations University.

Rosenberg, S. P. (2009). Responsibility to protect: A framework for prevention. Global Responsibility to Protect, 1, 442-477. doi:10.1163/187598509X1250 5800144837

Sanín, F. G., \& Wood, E. (2014). Ideology in civil war: Instrumental adoption and beyond. Journal of Peace Research, 51(2), 213-226. doi:10.1177/ 0022343313514073

Sharma, S., \& Welsh, J. (2012). Operationalizing the responsibility to prevent (Policy Brief, Oxford Institute for Ethics, Law and Armed Conflict). Oxford: University of Oxford.

South Asia Terrorism Portal. (2015). Fatalities in terrorist violence in Pakistan 2003-2015, SATP. Retrieved from http://www.satp.org/satporgtp/countries/ pakistan/database/casualties.htm\#

Stahn, C. (2007). Responsibility to protect: Political rhetoric or emerging legal norm? The American Journal of International Law, 101(1), 99-120.

Straus, S. (2008). The order of genocide: Race, power, and war in Rwanda. Ithaca: Cornell University Press.

Strauss, E. (2009). A bird in the hand is worth two in the bush-On the assumed legal nature of the responsibility to protect. Global Responsibility to Protect, 1, 291-323. doi:10.1163/187598409X450758

Thakur, R. (2011). The responsibility to protect: Norms, laws and the use of force in international politics. London and New York: Routledge.

Tilly, C. (2003). The politics of collective violence. New York: Cambridge University Press.

United Nations. (2005). World summit outcome (GA Res. 60/1). New York: United Nations.

United Nations. (2009). Implementing the responsibility to protect: Report of the Secretary General (A/63/677). New York: United Nations.

United Nations. (2013). Responsibility to protect: State responsibility and prevention (A/67/929- 
S/2013/399). New York: United Nations.

United Nations. (2014). Fulfilling our collective responsibility: International assistance and the responsibility to protect. (A/68/947-S/2014/449). New York: United Nations.

United States Commission on International Religious Freedom. (2013). USCRIF 2013 annual report. Washington: USCRIF.

Waxman, C. (2009). Intervention to stop genocide and mass atrocities (Council Special Report No49). New York: Council on Foreign Relations Press.
Weinstein, J. M. (2007). Inside rebellion: The politics of insurgent violence. New York: Cambridge University Press.

Welsh, J. M., \& Banda, M. (2010). International law and the responsibility to protect: Clarifying or expanding states' responsibilities? Global Responsibility to Protect, 2, 213-231. doi:10.1163/187598410X500363

Williams, P. R., Ulbrick, T. J., \& Worboys, J. (2012). Preventing mass atrocity crimes: The responsibility to protect and the Syria crisis. Case Western Reserve Journal of International Law, 1(45), 473-503.

\section{About the Author}

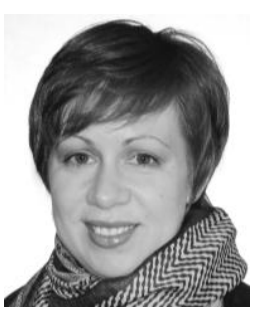

\section{Dr. Cecilia Jacob}

Cecilia Jacob is Research Fellow in the Department of International Relations, College of Asia and the Pacific, The Australian National University. She specializes in security studies, civilian protection and the Responsibility to Protect, with a focus on South and Southeast Asia. She is the author of Child Security in Asia: the impact of armed conflict in Cambodia and Myanmar (2014). 